\title{
MUSICAL PERFORMANCES IN THE HEBRIDEAN EXPERIENCE ECONOMY
}

[Received November 26th 2016; accepted June 2nd 2017 - DOI: 10.21463/shima.11.2.o7]

\author{
Sarah R. MacKinnon
}

sarahk@siar.fm

\begin{abstract}
In a world of increasingly undifferentiated goods and services experiences are said to be the next source of value-adding economic opportunity. Experiences differ from all other economic offerings by being inherently embodied and personalised and the experiences that can attach the most value will be those that are the most engaging and transformative. The experiential and transformational nature of tourism, and particularly island tourism, leads it to be a potential growth sector within an Experience Economy. This article explores how islanders within the Outer Hebrides of Scotland are (co-)creating engaging experiences through music performances in the form of festivals, ceilidhs, and bar sessions to increase tourism spend. This bottom-up approach to socio-economic development is novel in this context as musical performances in the Outer Hebrides have long been tied to the Gaelic language and culture. However, until recently they have not been considered a consumable economic offering. This article explores how using the lens of the Experience Economy offers new insights for islanders to generate tourism spend on their own terms.
\end{abstract}

KEYWORDS: Experience Economy, Tourism, Outer Hebrides, Archipelago, Music

\section{Introduction}

As material need has generally been met in the developed world there has emerged a new kind of need that can be described as "psychic gratification"; people, ie customers, are looking for meaningful experiences to which they can attach value in their lives (Boswijk, Thijssen and Peelen, 2007; Sundbo and Darmer (eds), 2008). In such a situation Pine and Gilmore (2011) advocate that businesses can no longer rely on ubiquitous products and services to achieve the greatest profit, they must stage memorable experiences that customers are willing to pay for. Pine and Gilmore use the model of theatre to explain how experiences should be constructed: the site of the experience should be considered a stage where people should act according to the overall theme of the experience. Disneyland is the prime example of a highly staged and choreographed experience where people are immersed in the Disney-themed world. Just as the 'Knowledge Economy' encompasses a range of industries from $R \& D$ to engineering, so too will the 'Experience Economy' (EE). In fact, Pine and Gilmore state that the EE will incorporate many economic sectors and industries such as hospitality, retail, financial services and manufacturing (ibid). They postulate that in a world largely saturated with "undifferentiated goods and services, the greatest opportunities for value creation resides in staging experiences" (Pine and Gilmore, 2013: 36). The key to staging successful and profitable experiences rests in reducing customer sacrifice and increasing customer satisfaction, this leads to the production of an element of surprise; and it is this surprise that adds value (both economic and personal) to the experience (Pine and Gilmore, 2000). 
Experiences are said to differ from all other economic activities by being inherently personal; therefore they are uniquely differentiated from person to person. Experiences are also manifold - they stimulate all the senses and the way in which they do so can be physically passive, like watching a play, or they can be deeply embodied like skydiving (Sundbo and Darmer, 2008: 2). Pine and Gilmore are at pains to stress that all experiences are not necessarily entertainment like the highly staged Disneyland, they can be educational such as virtual reality training simulations, esthetic such as standing at the precipice of the Grand Canyon, and escapist such as gambling at a casino. For an experience to garner the most economic value (ie be as profitable as possible) it must be consistently themed with even the smallest details adhering to, and supporting this overall theme, such as signage and any consumables (2011: 91). The best experiences (and thus those that command the greatest financial return) are those that yield personal transformations. It is perhaps for this reason that scholars appear to associate the EE most readily with the tourism industries (Baernoldt et al, 2004) where people pay to experience somewhere or something different that will leave them transformed through rest, adventure or education (eg see Powell et al, 2011 for a discussion of transformative effects of the Antarctic tourism experience). Tourism has frequently been cited as an experiential endeavour, even before conception of the EE model (eg Ryan, 1991; Wang, 1999; Sternberg, 1997). A "performance turn" in tourism studies has rejected the passiveness of the "tourist gaze" and emphasises the embodiment of the tourist experience, its multisensory and collaborative nature (Urry, 1990; Larson and Urry, 2011; Coleman and Crang, 2004; Sundbo and Darmer [eds], 2008). Tourism has been conceived as an experience that is different and new from the everyday life of the tourist (Urry, 2002, Urry and Larson, 2011). The staging of extra-ordinary tourist experiences has been described as follows:

most contemporary tourist scenes are staged, scripted experiences. A ship docks, or an airplane lands. The "players" make their entrances onto a set filled with local color, native artefacts, ethnic food, "typical" music, preselected aspects of culture and history, beachfront bars, gambling casinos, red-light districts, exotic or historic sites, souvenirs, folkloric entertainments, and other market-researched attractions... At the scheduled time, the players exit the scene and reboard the bus, ship or plane (Schwarz, 1997: xi-xii).

Islands are said to offer particular transformative experiences to tourists as places where people go to be changed through solace, reflection and escapism (Royle, 2001: 12; and see Irvine, 1984). Moreover, islands are said to comprise the ultimate ideal in terms of tourism experience in that the very requirement of crossing a body of water by plane or boat to get to the island assists the physiological feeling of separateness for the everydayness of continental life (Baum, 1997). Remote and small islands have often used their location, topography and cultural appeal to develop tourism industries. Islands in the Mediterranean and the Pacific have readily marketed their climates and islandness to construct a tourism product strongly associated with the 'island paradise' trope; places to go for sun, sea, sand and sex but also for relaxation and rejuvenation away from the frenetic pace of mainland life (Conlin and Baum, 1995). Islands are therefore a niche tourism product in themselves because they are islands, and thus islandness has an inherent economic value. This article explores the challenges for cold-water islands, such as the Outer Hebrides, to capitalise on their islandness. It will be demonstrated that while the traditional 'centre stage' of the Hebridean experience will continue to be the accessibility of the beautiful landscape, Hebrideans are creating new tourism-related revenue streams by staging innovative experiences that are culturally appropriate, immersive and co-produced with tourists themselves. 


\section{The Outer Hebrides}

The Outer Hebrides are an archipelago of fifteen inhabited (and many more uninhabited) islands that lie off the west coast of Scotland, in the North Atlantic. The islands form a long chain that extends some 200 miles from the most northerly point in the Isle of Lewis to the most southerly point on the Isle of Vatersay. The region forms one administrative region within Scotland and is home to 27,684 residents (2011 Census), 60\% of whom are bilingual, speaking both English and Scottish Gaelic to some degree. The region has one town, Stornoway, in the Isle of Lewis, (population 8,ooo) which acts as the administrative capital. The remainder of the population lives in small, dispersed settlements throughout the archipelago. It is at this juncture that the author must acknowledge her positionality as an islander, a Hebridean. Observations about the musical community are made from personal experience living, working, and socialising with island musicians and singers, and acting as the roadie for musical events.

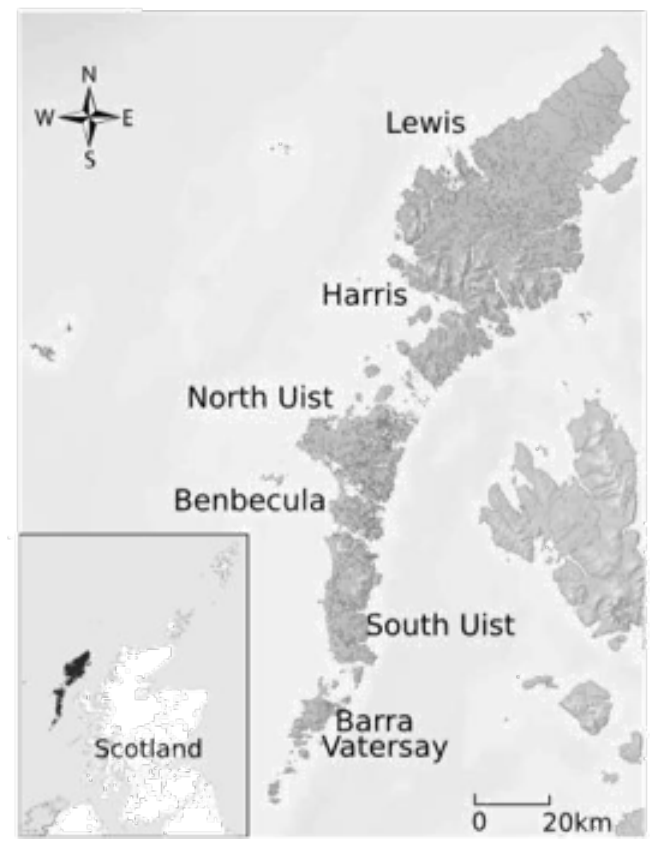

Figure 1 - Map showing the location of the Outer Hebrides (Adapted from Ordnance Survey)

The concept of development within the Outer Hebrides is synonymous with addressing and/or overcoming demographic challenges. Depopulation has been an insidious spectre in Hebridean development discourse since at least the creation of the Highlands and Islands Development Board in 1965 (see MacKinnon, 2014). Historically, the population of the Islands was decimated by waves of out-migration due to the Highland Clearances (see Devine, 2001) as well as boom and bust economic cycles like the growth and collapse of the herring trade (Keay and Keay, 1996). Between 1901 and 2001 the population of the Outer Hebrides declined from 46,172 to 26,502 (GROS, 2001). A recent modest growth in population between the 2001 and 2011 censuses of 1,182 people has been met with very cautious optimism as the Outer Hebrides' birth rate is one of the lowest in Scotland while 
the death rate is consistently the highest at 13.9 deaths per 1000 people (compared with the Scottish average of 11.3 deaths per 1000) (GROS, 2011). Population concerns are not unique to the Hebrides, many other North Atlantic islands also face ageing, declining populations. Between 1901 and 2002 the number of inhabited Irish islands decreased by more than half and the number of islanders decreased by more than two-thirds (Royle, 2003; Irish Census 2011). Canada's Cape Breton Island has had a falling population since the 1970s; while the population of Canada has grown by 52.4 per cent between 1971 and 2011, the population of Cape Breton Island has decreased by 20.4 per cent in the same period (CBRM, 2004). A lengthy trend of a falling population and a dispersed settlement pattern means that the Outer Hebrides, like many other small islands, are often characterised by what they lack: economies of scale, a sizeable labour force with a variety of skills and knowledge, and domestic markets (Royle, 2001, Baldacchino, 2002). In small islands there is often occupational pluralism, where people do several jobs as each is scaled down to the island situation (Royle, 20o1: 176) and this can often be true of those employed within local authorities who are employed in both the public and private sectors (Baldacchino and Bertram, 2009). This is true for the Hebrides where almost $45 \%$ of the working population are employed in the public sector (Office for National Statistics, 2010) and many are also involved in small tourism enterprises such as offering bed and breakfast or selling handicrafts.

Tourism has been debunked as a panacea for the woes of island economies. It can create competition for space (Canan and Hennessy, 1989); issues of access to formerly public areas; competition for resources (see Markwick, 2000); and leakage can see the financial returns of tourism projects leaving the place that is affected economically and socially by the influx of tourists (eg Royle, 1996). Furthermore, large numbers of tourists can cause social and cultural tensions related to cultural dilution (Conlin and Baum, 1995). Despite these challenges most islands still endeavour to develop successful tourism markets (Royle, 20o1: chapter 9) and those islands already popular with tourists often seek to attract more (eg see Isle of Man Visitor Economic Strategy, nd). Like other small islands that face declining resource-based industries and reduced tax bases as a result of falling working-age populations, tourism offers hope to the Outer Hebrides. The region's key development strategy 'Creating Communities of the Future' cites tourism as one of the key sectors of potential growth. Visitor numbers and tourism income have been consistently rising as shown in the table below and it is hoped that this will be a continuing trend:

\begin{tabular}{|c|c|c|}
\hline Year & Number of Visitors & Visitor Income \\
\hline 2002 & 179,696 & $£ 39.3$ million \\
\hline 2006 & 195,766 & $£ 49.9$ million \\
\hline 2013 & 218,196 & $£ 53.5$ million \\
\hline
\end{tabular}

Table 1 - Visitation figures for the Outer Hebrides (adapted from 2006 and 2014 Visitor Surveys by Sneddon Economics and Scotinform)

Table 1 - Table of Annual Visitors and Income 
While warm-water islands rely on the tried and tested brand of the tropical paradise, coldwater islands, like the Outer Hebrides, cannot do the same. Instead they offer a version of wilderness that invites adventure and exploration (Baldacchino, 2006a). However, coldwater islands are said to suffer from a 'double-punch' of cost and distance and consequently will appeal to a particular type of tourist who is prepared to incur these costs for the opportunity to visit such alternative destinations (Baldacchino, 2006b: 195). It is often cheaper for lowland Scots to visit other European countries than it is for them to visit their own islands but the typical anti-tourist to the Outer Hebrides is Scottish, over 45 years of age, travelling with their spouse or partner and in the upper-middle or middle class social group (2012-2013 Visitor Survey). Like other cold-water islands the 'double punch' results in a highly seasonal tourism industry (Baldacchino, 2006a, 2006b), limited to between approximately Easter and the end of September when the weather is most likely to be settled. Therefore there is only a short time when investment in tourism infrastructure and attractions can see a return. This seasonality can often result in higher charges for services and goods to offset their limited annual appeal (Butler, 1997). The Outer Hebrides therefore a face several challenges in attracting and increasing tourist spend, not to mention competition from Scotland's other archipelagos such as Orkney and Shetland who both have established tourism brands, unlike the Outer Hebrides (see Grydehøj, 2008 and MacKinnon, 2014).

\section{The Hebridean Experience}

Returning to Pine and Gilmore's postulation that successful and profitable experiences should be coherently themed; islands are at an advantage. They are themed by their inherent features of islandness working in concert, such as:

physical separation and isolation; access to abundant water... the sense of adventure in getting there, a manageable scale, a particular way of life, often at a slower pace than that on the mainland and a preserved culture and language. (Baum, 1997: 8).

The adventure in getting there is certainly true for the Isle of Barra where the airport 'runway' is one of the main visitor attractions. The 18 seater De Havilland Twin Otter plane that transports people between the island and Glasgow is scheduled to coincide with low tide as the runway is actually a beach called the Traigh Mhor ('Big Beach' in Scottish Gaelic). The runway is completely submerged twice a day at high tide. Tourists who have mainly arrived by sea often stand at the fence to the runway and watch the plane come in to land or take off. In this way, the journey to the Isle of Barra is a crucial part of the island experience, reinforcing that the fact that it is separate from the Scottish mainland, and the beach airport is part of the 'particular way of life'.

A 2014 Visitor Survey ( $\mathrm{n}=888$ ) states that the five main factors that influence people to visit the Outer Hebrides are the landscape, enjoyment of a previous visit, family connections, archaeology and a personal recommendation. The same survey states that the top activities undertaken by visitors when in the Outer Hebrides are visiting beaches, taking in the general scenery/sightseeing, going for walks, and visiting viewpoints/picnic sites. It is therefore the Hebridean landscape that draws people to visit and forms the basis of a Hebridean experience. The theme of the Hebrides is therefore primarily their islandness; while travelling around the region the sea is an almost continual companion, it is difficult to escape the constant reminder that one is 'islanded'. The stunning white sandy beaches of

Shima Volume 11 Number 22017 
the archipelago have few, if any, people on them even in the height of the summer season offering a sense of freedom that is difficult to find on warm-water counterparts. The island theme is supplemented by ample evidence that the Outer Hebrides is a Celtic and a Gaelic place. Main road and street signs have Gaelic first with a smaller English translation underneath while smaller side roads signs are often only in Gaelic underneath while smaller side roads signs are often only in Gaelic.

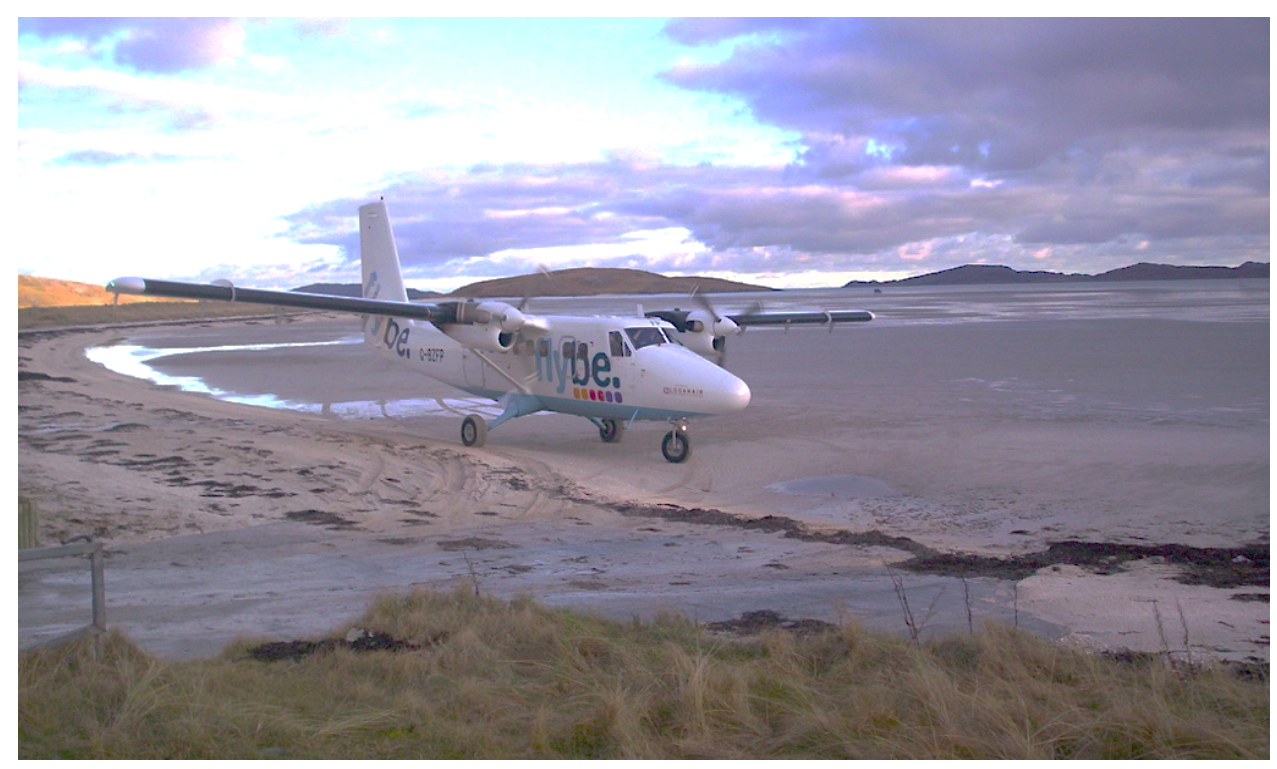

Figure 2 - Standing on the 'runway' at low tide looking at Barra Airport (author's photo)

The Hebridean landscape therefore forms the stage and the backdrop for the Hebridean experience. Low population density and low tourism penetration means that visitors can experience the typical cold-water ideal of a place that is not a tourist resort but an uncommercialised place to be explored at one's leisure. Pine and Gilmore suggest a carefully staged experience where employees or participants are to act in accordance with the theme can charge for the experience through various forms of admission. However, it is significant to note that the majority of attractions of the Hebrides do not charge any type of fee nor require much input from islanders. Beaches and the wider landscape are free to be roamed and many of the historically significant sites are open access. Admission fees run contrary to the strong sense of communal access to land and the environment that is at the heart of the crofting and Gàidhlig (Scottish Gaelic) culture so it likely to be an unattractive prospect for natural attractions. To give an example, the Callanish Standing Stones on Lewis receive over 42,000 visitors per year and there is no type of entrance fee because the stones are perceived to belong to everyone on the islands. There is a visitor centre at the foot of the Callanish site where tourists can purchase teas and coffees but this is incidental, many tourists then visit the Stones without spending money. Further, outside Stornoway the opportunities for spending money are few and far between, particularly in the late evenings and weekends. This poses a conundrum: how do the Outer Hebrides increase tourist spend when the basis of the Hebridean experience is free? 


\section{Music and the Hebridean Experience Economy}

Like most societies, songs and musical performances in Outer Hebrides play a pivotal role in life's great landmarks such as births, love affairs, marriages, and deaths (see Bennett, 2012), they also help with the tedium of physical work, for example, waulking songs helped Hebridean women clean and soften tweed into workable fabric (see Burnett and Burnett, 2011). Moreover, songs and music in these islands are interwoven through the fabric of time; many songs act as a form of collective memory; telling tales of injustices of the past (such as the Clearances) and the resulting personal trials of separation and long lost loves. (See Burnett and Burnett, 2001; and Gillies, 2010 for a history of Hebridean songs). Hebridean songs are also almost entirely sung in the Scottish Gaelic language. Below is one such example, an abridged version of 'O mo Dhùthaich' ('Oh, my land'). It is the story of a Uist man who was promised a land of milk and honey in Canada but found only sadness and despair. The song is a warning to his family and friends back in Uist not to fall for the landowners promises of a better life abroad. Many Scottish Gaelic-language songs also act as a cultural link between the Gaels of the Highlands and Islands of Scotland and the wider diaspora in the United States and in Canada, where there continue to be Gaelic speakers today (for example, see the Cape Breton tourism website).

O mo dhùthaich 's tu th' air m' aire Uibhist chùbhraidh ùr nan gallan, Far a faicte na daoin' uaisle, 'S far bu dual do Mhac 'ic Ailein.

Chan eil buaidh nach eil ri àireamh Air Uibhist os cionn gach àite

$N$ t-eilean garbh mun iadh an sàile Gheibh an strainnsear aoigh is blàths ann.

'S gura mise tha gu cràiteach 'S trom mo cheum, neo-aotrom tha $\mathrm{mi}$ On a dhealaich mi rim chàirdean Thuit mo chridhe 's mo chèol-gàire

S ann a thig 'ad, carach, seòlta Gus ar mealladh far ar n-eòlais; Molaidh iad dhuinn Manitòba, Dùthaich fhuar gun ghual, gun mhòine.

Nam biodh agamsa de stòras Dà dheis aodaich, 's paidhir bhrògan

Agus m' fharadh ann am phòca 'S ann air Uibhist dhèanainn seòladh.
Oh, my land you're always in my thoughts, fresh, fragrant Uist, home of heroes, where the noble people live, hereditary territory of Clanranald.

There is not a single way in which Uist is not richer than all other places the bushy island bounded by the sea: the stranger will find hospitality and warmth there.

Oh, I am distressed, my step is heavy, I am sombre: since I parted from my friends, my heart and my laughter have wilted away.

They come to us wily and cunning, to seduce us from our homeland: they sing the praises of Manitoba a cold country without coal, without peat.

If only I were rich enough, to possess a change of clothes, a pair of shoes, and my fare in my pocket, I would set sail straight away for Uist.

Despite the importance of songs, music, and ceilidhs in Hebridean culture, they have not featured significantly in the Hebridean tourism experience until recently. In visitor surveys between 1998 and 2011 musical events were not listed in the range of available activities to 
choose as having partaken in during a Hebridean holiday. The visitor survey for the 20122013 summer season indicates that only $11 \%$ of holiday makers listened to any kind of traditional music while in the archipelago, this is lower than both Orkney (12\%) and Shetland (19\%). It should be noted that the 2012-2013 Visitor Survey results are compiled from several sources including face-to-face interviews $(n=1,262)$, online surveys $(n=888)$, and calibration surveys $(n=5,467)$ over the course of a year. The variation in methods and timings of data collection should be noted as these will have an impact on results. However, the low numbers of people reporting attending a musical performance is not surprising for a number of reasons. The primary site of musical performance, the ceilidh, was until recent times essentially a closed event. The private nature of ceilidhs in people's homes effectively excludes visitors unless invited by a personal invitation. Secondly, until the recent rise of social media, news of a ceilidh, even in a village hall, was often spread by word of mouth or in small local newsletters that are not immediately apparent to visitors. Furthermore, centuries of suppression of the Gaelic language and culture by the lowland Scottish and British ruling classes created an internalised sense of inferiority in Gaelic speakers that is beginning to be rectified by government recognition and funding (see MacAuley, 1992; Oliver, 2005; McEwan-Fujitsu, 2010). It was therefore inevitable that when the language of Hebridean songs is considered of lesser value to English their role in selling the Hebrides as an experience has been somewhat overlooked.

Since the 1970s Scotland has had somewhat of a Gaelic revival and, as part of this, Scottish Gaelic music has seen a growth in popularity (alongside increasing governmental support for the language) with many acts gracing the stages of both Scottish and international musical festivals (McKean, 1998), for example the trad-pop group Mànran. Concurrently, there was also a rise in the ill-defined genre of Celtic music (see Symon, 2002). The first Hebridean Celtic Festival was held in 1996 with the aim of of bringing professional Celtic musicians to the Isle of Lewis. This first festival was organised by islanders and attracted around 1,00o people, mainly from the local area (ibid). In 2016 the festival had over 7,500 paying customers, of which almost $70 \%$ came from outside the Isles of Lewis and Harris, with three-quarters of these people stating they were in the Hebrides specifically for the event. The festival directly generated $£ 1.4$ million for the local economy with another £o.8 million indirectly and is said to support 40 tourism-related jobs (festival website, 2016). Over the course of the past 21 years the festival has generated more than $£ 20$ million for the Hebridean economy and developed from a small local event to an "international showpiece" for "Celtic and traditional music" (ibid). International acts have included Hayseed Dixie and Van Morrison as well as Scottish favourites such as the Red Hot Chilli Pipers and Runrig. Despite the growth of the Hebridean Celtic Festival and its 'internationalisation' organisers still want to promote its localness and do so by making the Gaelic language visible throughout the event; stewards wear t-shirts emblazoned with the words 'tha Gàidhlig agam' (I speak Gaelic) and local businesses are showcased through market stalls inside the festival area. 


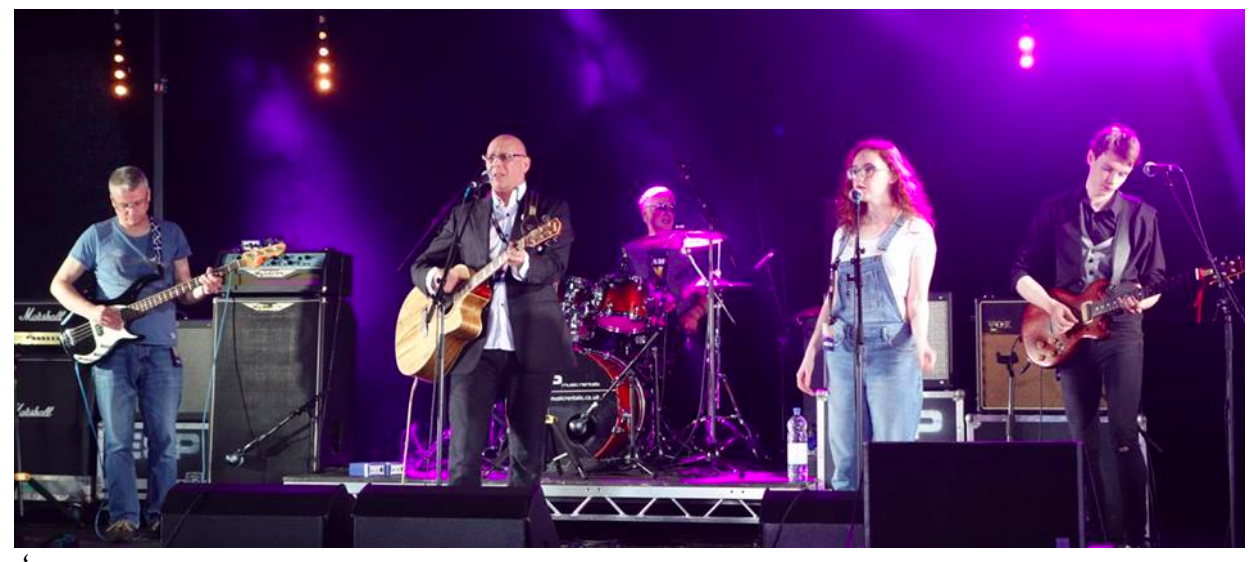

Figure 3 - The Shed performing at EDF in 2016 (author's photo)

The success of the Hebridean Celtic Festival has spurred the creation of the Eilean Dorcha Festival (EDF), based on the Isle of Benbecula. The first EDF happened during July 2016 and much like the early days of the Hebridean Celtic Festival attracted a mainly local audience of around 1,00o to watch Hebridean acts. The organisers of EDF no doubt have ambitions to replicate the growth and success of its Lewis predecessor. Both of these events market themselves as professionally staged events that not only incorporate music but also local food and craft stalls, storytelling, shinty matches and Highland dancing competitions.

Traditional music experiences also occur in island bars and pubs. This may be in a formal setting where musicians are paid to play and entertain customers but it is also common that musicians will gather out of tradition rather than arrangement and have a 'session'. The session not only refers to the act of playing music together but also to the copious amounts of alcohol that are consumed at such gatherings. At such events tourists are inevitably enraptured by something that is perceived as authentic and unstaged, the antithesis of the large music festivals. Authenticity is an important concept within tourism (see Wang, 1999; MacCanell, 1989) and in EE literature, however it remains notoriously difficult to define. Authenticity is not a synonym for "realness" and an antonym for "fakeness" (Pine and Gilmore, 2011: 56), instead it implies sincerity, genuineness and originality (Boswijk, Thijssen and Peelen, 2007). This sense of authenticity or sincerity at sessions is only reinforced when attempts at recording or photographing the performers without first asking permission may result in a stern verbal warning or a glare, adding to the pleasure of blending in by other tourists in the vicinity. It is not unheard of for bars to buy musicians drinks in order that they keep playing if there is a particularly engaged tourist audience, in order to increase tourist spend on drinks. However, any tourist expecting to hear a session may be disappointed due to the informality and thus unpredictability of these events. The musicians play for their own pleasure throughout the year and not necessarily to entertain tourists during the summer. The author's husband plays guitar and sings at these sessions throughout the year to keep his Gaidhlig and musical skills sharp as well as being an active contributor to the vibrancy of the local culture. Sessions are not unique to the Hebrides, similar events occur across Scotland and Ireland. The Orkney Folk Festival advertises these as an integral part of the festival experience: 
sessions are very much are organic affairs that quickly take on a life of their own - they are not performances. Joining in is very much encouraged and it's not uncommon for a midday session to end at closing time, creating one-off collaborations, as well as meetings and exchanges of traditions and tunes along the way. It may even be that a session's natural momentum is that strong that a band due to take the reins might not even be able to squeeze their way in - but that's absolutely fine by us. If the tunes are already in full flow, they will always take precedent. Despite the best will in the world, true session magic can't be planned (Orkney Folk Festival website, nd).

It is in the ad hoc nature of these sessions that tourists experience the greatest element of surprise and mystery as there are no clear rules on how many performers will attend, what they will play and for how long they will play. Pine and Gilmore state that surprise is perhaps the single most important ingredient required in the successful staging of experiences. Further, surprises transcend customer (ie tourists') expectations and this leads to increased satisfaction. Over the years, visitor surveys have provided an insight into tourists' perceptions of the Outer Hebrides and they have been asked to make comments on anything they particularly enjoyed or disliked about their trip. The 2011 survey commonly cited the lack of adequate signage to sites of interest as detracting from their experience. The second most common comment of dissatisfaction from tourists was with the weather (see Table 2). Hebrideans have little control over the weather, however it would suggest that there are insufficient indoor attractions and facilities to provide tourists with a positive experience regardless of the elements. This is an important source of potential in the Experience Economy, where a negative aspect (sacrifice) could be transformed into positive part of the overall theme of the islands.

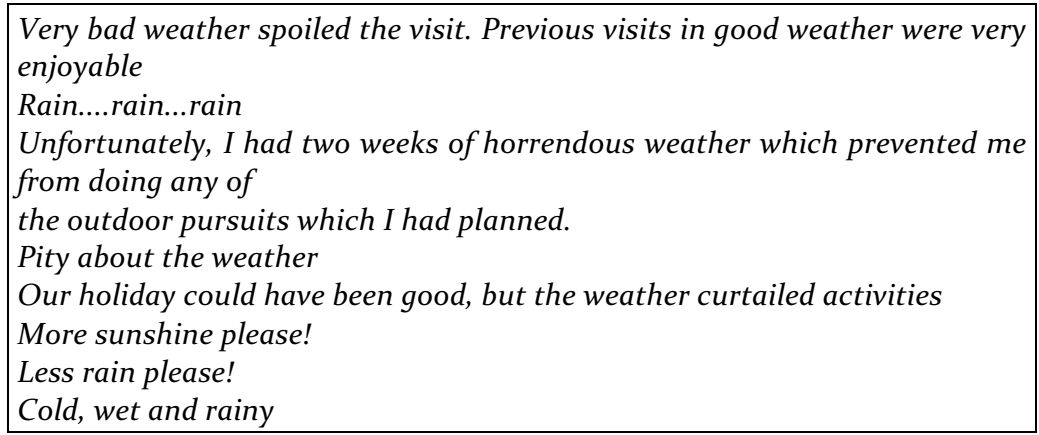

Table 2 - Dissatisfied comments about the weather from the 2011 Visitor Survey

Until recently, performances of songs like 'O mo Dhùthaich' were principally in the form of household ceilidh. Donald MacKenzie, in 1917, describes the purpose and setting of these 'gatherings':

On long, dark winter nights it is still the custom in small villages for friends to collect in a house and hold what they call a "ceilidh"... Young and old are entertained by the reciters of old poems and legendary stories which deal with ancient beliefs, the doings of traditional heroes and heroines, and so on. Some 
sing old and new songs set to old music or new music composed in the manner of the old. (1917: 14)

While storytelling has fallen out of fashion (see MacLean, 1956) the musical element of ceilidhs still exists in the Hebrides, albeit in a slightly different setting. While ceilidhs do still occur in Hebridean homes, they are now more established in community halls. A greater seating capacity and the presence of audio equipment mean that village hall ceilidhs are whole-community meeting events rather than a small group of family and friends. These gatherings are still social events that break up the long winter when many of the amenities that are available during the summer tourist season are closed; equally, they also play an important role in the transmission of the Gaelic oral tradition (see Sheridan, MacDonald and Byrne, 2011).

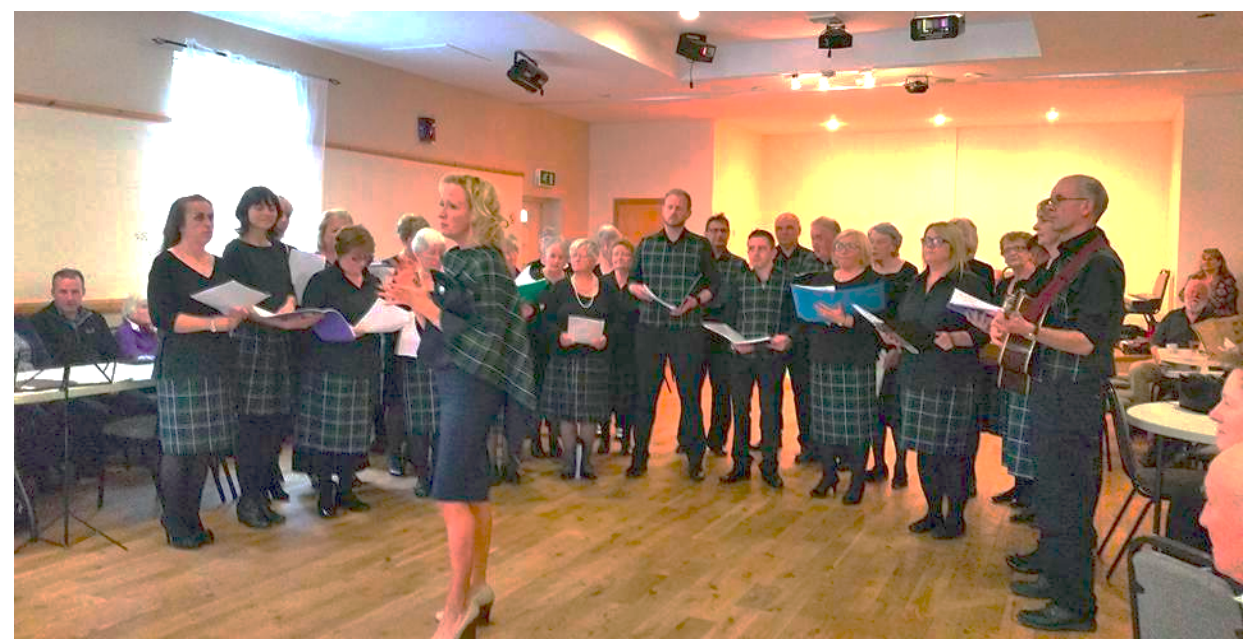

Figure 4 - Barra Gaelic Choir performing at a fundraising ceilidh (source: Còisir Ghàidhlig Bharraigh)

The conductor of Barra Gaelic choir recognised the potential in hosting regular ceilidhs every Sunday night in a community hall throughout the 2016 summer season (July and August). The reasons for doing so were threefold. Firstly, these ceilidhs provided valuable performance practise for the Barra Gaelic choir, secondly they provide a regular, advertised cultural experience through the medium of Gaelic which may be the only opportunity for tourists to do during their short stay, and thirdly, by having a donation box at the door the choir raises much needed funds for travelling off-island to competitions. Between each song someone will give a brief description of the narrative so that those who do not speak Gàidhlig may still appreciate the tone and mood of each song. As well as listening to traditional Gaelic songs visitors are welcome to play and sing their own folk tunes if they wish. At one ceilidh a visiting Anglican priest sang the English language anti-war song 'Where have all the flowers gone?' As well as singing or playing an instrument the audience at a ceilidh have an important role to play in keeping time for performers either by clapping or tapping their foot or a combination of both. Ceilidhs are often 'bring your own bottle' with islanders supplying home-baking or a 'pot-luck' supper. Visitors are therefore, potentially, not passive audience members but co-producers of this musical experience, a key element of success in the EE. Furthermore, participation through time-keeping and 
singing means visitors are not just listening and watching but moving, eating and drinking, making the experience truly multi-sensory. Coproduction of experiences in the Scottish islands differ from the 'servicescape' of Polynesian musical performances such as the luau, where there is typically a distinct boundary between performer and consumer (Rosenbaum and Wong, 2007). In fact, when talking to visitors at such events several told the author how surprised they were to be welcomed with such open arms and encouraged to participate. In this regard, visitors are again surprised at the central role they can play in the co-production of the ceilidh experience.

\section{Discussion}

The Hebridean experience is closely related to the freedom of exploring dramatic landscapes and visiting in situ historical sights. While the principal attractions of the islands are free to access they are also largely weather dependent. The weather in Autumn and Winter (October - March) is some of the worst in the British Isles with wind speeds often over 70 miles per hour and almost daily driving rain. This not only makes the key attraction of the Hebridean landscape less appealing for half of the year but also hinders potential off-season travellers as plane and ferry journeys are frequently delayed or cancelled. Even during summer months Hebridean weather is unpredictable and changeable. It is here that the Hebrides has both a challenge and an opportunity. Negative comments in visitor surveys indicate that there is a lack of entertainment and activities when the weather is inclement. Therefore, in order to optimise the Hebridean experience and increase spending via visitor satisfaction the region must address the negative impact of the weather on the tourist experience. Some islanders have recognised that this challenge can be transformed into an opportunity with the potential to generate additional income in the form of more staged, orchestrated, indoor (wet-weather) activities that as yet remain largely absent or in the exploratory stages. Islanders are ensuring the sustainability of musical ventures by using existing infrastructure such as community halls and starting festivals on a small, manageable scale. Passivity in economic activities is said to limit potential earning (Pine and Gilmore 2011: 35) and Hebrideans are mindful of this when staging or hosting musical events; visitors are encouraged to co-produce ceilidhs, becoming more than the passive listeners that frequent typical luaus but constructors of their own experience. Aside from the acknowledged economic benefits of the larger music festivals, further research is required to determine the economic impact of ceilidhs and sessions on local economies.

The growing popularity of music festivals and public ceilidhs are increasing the exposure of Hebridean musical performances to outside audiences. What were once exclusive, by their location and their language, to Gaelic-speaking audiences are now being transmitted not only outwith a Hebridean audience but outwith a Scottish audience. This is important for reifying the musical and oral tradition of a region and culture that have faced centuries of suppression and resulting internalised self-consciousness. The opening up of Hebridean musical performances to outsiders as part of a cultural tourism product raises several questions. As the popularity of Hebridean musical festivals grow, how do organisers continue to market the localness of these events when musical acts and increasing numbers of ticket holders originate not just outside the Hebrides but outside Scotland? How does the shift of ceilidhs from a closed form of entertainment to an income generating event, particularly in a time when Islanders have many other forms of entertainment in the winter such as online streaming, affect their purpose and therefore their perceived authenticity? Furthermore, how does the very act of outsiders, ie tourists, seeing these

Shima Volume 11 Number 22017

$-67-$ 
events, never mind photographing and participating in them, change their very nature (Berger, 2008; Ek et al, 2008)? Ceilidhs and pub sessions have shifted their purpose from being a purely community-focused form of cultural (re)production and transmission to becoming a consumable experience where the expectations and sensibilities of 'others' are to be considered. The inclusion of non-traditional, non-Gaelic songs and English explanations between Gaelic songs reduces the primacy of Gaelic in another sphere where it was once the primary medium of communication. Therefore, there is further research to be done on how Hebridean musical performances are changing as they become part of an Experience Economy.

Tourism is unlikely to become the panacea for Hebridean economic and demographic challenges and instead will continue to contribute to a multi-sectoral economy. Islanders in the region realise the potential double-edged nature of tourism growth (Royle, 2001: 206), such as issues around what has been termed "Disneyfication" (Shackley, 2001; Royle, 1999, 2003). Places like the Outer Hebrides face challenges in receiving returns for investment in Experience Economy industries like tourism due to seasonality, peripherality and cultural hesitation to engage with a sector with a well-known appetite for destruction (eg Holden, 2003). However, the EE may provide a way for islands to do tourism on their own terms and exploit the anti-tourist appeal for financial return. In this sense the Hebrides are in a fortunate position that they are indeed in the early stages of their tourism destination development and have the opportunity to grow the industry in a socially and environmentally sensitive way (Butler, 1991). The constraints placed on the numbers of tourists by peripherality and associated seasonality may act as a pressure release valve on the long-term success of the place, thus ensuring enduring appeal and continuing returns for what appear to be authentic Hebridean experiences. While music festivals and ceilidhs are undoubtedly becoming increasingly important cultural and economic offerings they will not be, in and of themselves, the solution to historical Hebridean demographic challenges. The sectionality of these experiences within the tourism industry means that they may not provide the type or quality of jobs that would attract islanders back from the mainland or new in-migrants, due to their seasonality and infrequency (Baum, 1996). Instead they are likely to add to the occupational pluralism that exists within the region.

\section{Conclusion}

Islands have an inherent advantage in an EE; islandness itself is experiential and therefore people are willing to pay to be 'islanded'. Where warm-water islands can take advantage of high tourist numbers, long tourism seasons and the opportunity to offer water-related activities like snorkelling or jet-skiing, cold-water islands are not in the same position. A stunning landscape, a distinctive culture and language, and a sense of freedom combine so the Hebrides offer the idyll of a cold-water island experience. However, seasonality, cost of transportation and archipelagity result in dispersed and limited markets and therefore much of the tourism infrastructure such as shops, restaurants, galleries etc. remain largely absent outside the only town of Stornoway. While music and song are an integral part of the Hebridean culture and sense of identity, they have not, until recently, been considered a consumable aspect of the tourist experience. Islanders have begun to realise that by opening up musical events such as ceilidhs and bar sessions, not just to be observed by tourists but to be co-produced by them, is a meaningful (and perhaps authentic) way of improving their overall experience of the Hebrides. While the draw of the Hebridean landscape will no doubt continue to be the central 'stage' of the Hebridean experience, musical performances offer opportunities for islanders to produce an experience on their own terms, at a time and place of their choosing, while at the same time allowing visitors to

Shima Volume 11 Number 22017 
co-produce a multisensory experience. This offers increased opportunity for visitors to contribute financially to local charities and organisations through their donations, increase spend in bars during sessions, and of course through ticket and accommodation fees at festivals. The opening up of musical performances in the Hebrides also raises new questions about the function and nature of these performances that merit further research.

\section{BIBLIOGRAPHY:}

Bærenholdt, J.O, Haldrup, M, Larsen, J and Urry, J (2004) Performing tourist places, Farnham: Ashgate Publishing Ltd

Baldacchino, G (2002) 'Jurisdictional self-reliance for small island territories: considering the partition of Cyprus', The Round Table v91 n365: 349-36o

----- (ed) (2006a) Extreme tourism: Lessons from the world's cold water islands, Oxford: Elsevier

----- (2006b) 'Warm versus cold water island tourism: a review of policy implications', Island Studies Journal v1 n2: 183-200

---- (2012) 'The Lure of the island: A spatial analysis of power relations', Journal of Marine and Island Cultures v1 n2: 55-63

Baldacchino, G and Bertram, G (2009) 'The beak of the finch: Insights into the economic development of small economies', The Round Table v98 n401: 141-16o

Baum, T (1997) 'The fascination of islands: a tourist perspective. Island tourism: Trends and prospects', in Lockhart, D and Drakakis-Smith, D (eds) Island Tourism: Problems and Perspectives, London: Pinter: 21-35

Bennett, M (2012) Scottish Customs: From the Cradle to the Grave, Edinburgh: Birlinn

Berger, J (2008) Ways of Seeing, London: Penguin

Boswijk, A, Thijssen, T and Peelen, E (2007) The experience economy: A new perspective, London: Pearson Education.

Butler, R (1991) 'Tourism, environment and sustainable development', Environmental Conservation v18 n3: 201-209

Butler R (1997) 'Modelling tourism development: evolution, growth and decline', in Pigram, J and Wahab, S (eds) Tourism, Development and Growth: The Challenge of Sustainability, London: Routledge

Burnett, R and Burnett, K (2011) 'Scotland's Hebrides: Song and Culture, Transmission and Transformation', in Baldacchino, G (ed) Island Songs: A Global Repertoire, Plymouth: Scarecrow Press, 81-102

Cannan, P and Hennessy, M (1989) 'The growth machine, tourism, and the selling of culture', Sociological Perspectives v32 n2: 227-243 


\section{MacKinnon: Musical Performances in the Hebridean Experience Economy}

CBRM (2004) 'Population Projections for Cape Breton Municipal Units - 2001-2021': www.cbrm.ns.ca - accessed 16th May 2017

Central Statistics Office (2011) '2011 Irish census': http://www.cso.ie/en/census/index.html accessed 2oth May 2017

CnES, (2010) 'Creating Communities of the Future': http://www.cnesiar.gov.uk/creatingcommunities/index.asp - accessed 18th February 2017

Coleman, S and Crang, M (2004) Grounded tourists, travelling theory in Tourism: Between Place and Performance, Oxford: Berghahn Books

Conkling, P (2007) 'On Islanders and Islandness', Geographical Review v97 n2: 191-201

Conlin, M.V and Baum, T (1995) Island tourism: management principles and practice, Chichester: John Wiley and Sons.

Devine, T.M (2001) The Scottish Nation 170o - 200o, London: Penguin

Ek, R, Larsen, J, Hornskov, S.B and Mansfeld O.K (2008) 'A Dynamic Framework of Tourist Experiences: Space-Time and Performances in the Experience Economy', Scandinavian Journal of Hospitality and Tourism v8 n2: 122-140.

General Register Office for Scotland (2001) '2001 Census results': http://www.groscotland.gov.uk/census/censushm/ - accessed 2nd November 2016

General Register Office for Scotland (2011) 'Estimated population, births, stillbirths, deaths, marriages and civil partnerships, numbers and rates, by administrative area, Scotland, first quarter, 2011': http://www.gro-scotland.gov.uk/ - last accessed 3rd November 2016.

Gillies, A.L (2010) Songs of Gaelic Scotland, Edinburgh: Birlinn

Gillis, J.R (2004) Islands of the Mind: How the Human Imagination created the Atlantic World, London: Macmillan.

Grydehøj, A (2008) 'Branding From Above: Generic Cultural Branding in Shetland and other Islands', Island Studies Journal v3 n2: 75-198

Hebridean Celtic Festival (2016) 'Record-breaking Hebcelt worth $£ 2.2$ million to islands': https://www.hebceltfest.com/news/?id=235\&view=full - accessed 17th November 2016

Hjorth, D and Kostera, M (2007) Entrepreneurship and the Experience Economy, Copenhagen: CBS Press

Holden, A (2003) 'In need of new environmental ethics for tourism?', Annals of Tourism Research v30 n1: 94-108

Isle of Man Government (2013) 'Isle of Man Visitor Economic Strategy': http://www.gov.im/

- last accessed ist December 2013 


\section{MacKinnon: Musical Performances in the Hebridean Experience Economy}

Irvine, L (1984) Castaway, London: Penguin Books

Keay, J and Keay, J (1996) Collins Encyclopaedia of Scotland, London: HarperCollins

Larsen, J and Urry, J (2011) 'Gazing and performing', Environment and Planning D: Society and Space v29 n6: 1110-1125

MacDonald, F (2002) 'The Highlands as spectacle', in Coleman, S and Crang, M (2002) Grounded tourists, travelling theory in Tourism: Between Place and Performance, Oxford: Berghahn Books: $54-74$

MacAuley, D (1992) 'The Scottish Gaelic Language', in MacAuley, D (ed) The Celtic Languages, Cambridge: Cambridge University Press: 137-248

Mackenzie, D.A (1917) Wonder Tales from Scottish Myth and Legend, Glasgow: Blackie and Son

MacKinnon, S.R (2014) 'Coping with insularity: social and economic development in a small island setting', (unpublished) PhD thesis, Queen's University Belfast

MacLean, C.I (1956) ‘Hebridean Traditions', Gwerin v1 nı: 21-22

MacPhearson Research, (2012) 'Outer Hebrides tourism visitor survey 2011': www.cnesiar.gov.uk - accessed 3rd December 2013

McKean, T (1998) 'Celtic Music and the Growth of the Féis Movement in the Scottish Highlands', Western Folklore v5 n4: 245-259

Markwick, M.C (200o)' Golf tourism development, stakeholders, differing discourses and alternative agendas: the case of Malta', Tourism Management v21 n5: 515-524

McEwan-Fujita, E (2010) 'Ideologies and Experiences of Literacy in Interactions Between Adult Gaelic Learners and First-Language Gaelic Speakers in Scotland', Scottish Gaelic Studies v26: 87-114

Nova Scotia Canada (nd) 'Find your Celtic heart': http://www.novascotia.com/explore/road-trips/celtic-cape-breton - accessed 2nd June 2017

Office for National Statistics (2010) 'Sub-regional public and private sector employment': www.ons.gov.uk - accessed 2nd November 2016

Oliver, J (2005) 'Scottish Gaelic Identities: Contexts and Contingencies', Scottish Affairs v51 n1: $1-24$

Orkney Folk Festival (nd) website: http://www.orkneyfolkfestival.com/pub-sessions/ accessed 2nd June 2017

Pine, B.J and Gilmore, J.H (200o) 'Satisfaction, sacrifice, surprise: three small steps create one giant leap into the experience economy', Strategy and Leadership v28 n1: 18-23 
Pine, J and Gilmore, J (2011) The experience economy, Massachusetts: Harvard Business Press

Pine, J and Gilmore, J (2013) 'The experience economy past present and future', in Sundbo, J and Sørensen, F (eds) Handbook on the Experience Economy, Cheltenham: Elgar Publishing: 21-44

Powell, R.B, Brownlee, M.T, Kellert, S.R, and Ham, S.H (2012) 'From awe to satisfaction: immediate affective responses to the Antarctic tourism experience', Polar Record v48 n2: $145-156$

Rosenbaum, M.S and Wong, I.A (2007) 'When Tourists Desire an Artificial Culture: the Bali Syndrome in Hawaii', Tourism Management: Analysis, Behaviour, and Strategy v1 n2: 174184

Royle, S.A (1999) 'From Dursey to Darrit-Uliga-Delap: an insular odyssey', Irish Geography v32 n1: 1-8

----- (1996) 'Mallorca: the changing nature of tourism', Geography Review v9: 2-10

----- (2001) A Geography of Islands, London: Routledge

---- (2003) 'Exploitation and celebration of the heritage of the Irish islands', Irish Geography v36 n1: 23-31

Ryan, C (1991) Recreational tourism: A social science perspective, Oxford: Routledge

Schwarz, R (1997) Pleasure Island: Tourism and Temptation in Cuba, Nebraska: University of Nebraska Press

Scotinform (2014) 'Outer Hebrides visitor survey 2012/2013 Research results - Final Report': http://www.visitscotland.org - accessed 19th November 2016

Shackley, M (2001) 'Potential Futures for Robben Island: shrine, museum or theme park?', International Journal of Heritage Studies v7 n4:355-363

Shepherd, S (2004) 'Fractures of culture: towards an anthropology of development on East Timor', Studies in Languages and Cultures of East Timor v6: 100-118

Sheridan, M, MacDonald, I and Byrne, C.G (2011) 'Gaelic singing and oral tradition', International Journal of Music Education v29 n2: 172-190

Sneddon Economics (2007) 'Outer Hebrides tourism facts and figures update: review of 2006 season': www.cne-siar.gov.uk - accessed 2nd November 2016

Sternberg, E (1997) 'The iconography of the tourism experience', Annals of Tourism Research v24 n4: 951-969

Sundbo, J and Darmer, P (2008) 'Introduction', in Sundbo J and Darmer, P (eds) Creating Experiences in the Experience Economy, Cheltenham: Edward Elgar Publishing: 1-12 
Sundbo, J and Darmer, P (eds) (2008) Creating Experiences In The Experience Economy, Cheltenham: Edward Elgar Publishing

Symon, P (2002) 'From blas to bothy culture: the musical remaking of Celtic culture at the Hebridean Celtic festival', in Harvey, D.C, Jones, R, McInroy, N and Milligan C (eds) Celtic Geographies: cold cultures, new times, London; Routledge: 192-207

Urras nan Tursachan (2015) 'Callanish Visitor Centre Redevelopment: The story so far...': https://callanishvisitorcentre.wordpress.com/last accessed 15th November 2016

Urry, J (1990) The Tourist Gaze, London: Sage

----- (2002) Consuming places, Oxford: Routledge

Urry, J and Larsen, J (2011) The Tourist Gaze 3.o, London: Sage Limited

Wang, N (1999) 'Rethinking authenticity in tourism experience', Annals of Tourism Research v26 n2: 349-370 